\title{
Holding On and Letting Go: A Perspective from the Keystone IV Conference
}

\author{
Kurt C. Stange, MD, PhD
}

This commentary examines what it might look like to be countercultural in the current era of health care change, and asks what we should hold onto and what we should let go of as we reinvent an ideal that gives meaning to family physicians and value to patients and populations - that primary health care is a relationship to be nurtured and supported, not just a commodity to be delivered and optimized, measured and incentivized, bought and sold.(J Am Board Fam Med 2016;29:S32-S39.)

Guest editors' note: This paper captures ideas presented in reaction to the initial presentations at the G. Gayle Stephens Keystone IV Conference. It goes further to reflect on the purpose of the conference and the opportunities for family medicine during this transitional time in health care, as discerned by an exceptionally well-informed journal editor and thought leader for primary care and personal doctoring.

Keywords: Doctoring, Family Medicine, Family Physician, Health Care Delivery, Personal Physician, Population Health, Primary care, Professionalism, Social Justice

From the moment of birth, we have the instinctual ability to grasp objects. By 5 months the grasping becomes purposeful-we grab and hold onto what we want.

Letting go is harder. For a few months, when holding onto a rattle, an infant will look longingly at a new, shinier rattle- then look back at the dull rattle in hand, and then back to the shiny rattle, unable to let go of the old to grasp the new. ${ }^{1}$

Not much later, we learn to let go to grasp. But letting go remains the more difficult action.

I relearned that lesson this fall. Reaching to put garden hoses into my garage attic for the winter, the ladder wavered, then toppled. Despite feeling the fall, I kept holding on to the hoses, rather than

This article was externally peer reviewed.

Submitted 29 December 2015; revised 18 April 2016; accepted 25 April 2016.

From the Department of Family Medicine \& Community Health, Case Western Reserve University, Cleveland, OH.

Funding: none.

Conflict of interest: none declared.

Corresponding author: Kurt C. Stange, MD, PhD, Department of Family Medicine \& Community Health, Case Western Reserve University, 11000 Cedar Ave, Ste 402, Cleveland, OH 44106-3069 (E-mail: kcs@case.edu). reaching out to grab something to disrupt the tumble.

Fortunately, the cement floor broke my fall, and I was roughly OK. Still, the bruises reminded me for weeks of the strength of the instinctual drive to keep hold of what is in hand.

Holding on and letting go were among the challenges of the fourth G. Gayle Stephens Keystone Conference in Colorado, as participants strove to answer the question, "What promises will a personal physician make to her/his patients going forward in the evolving health care system of the United States, particularly in terms of when and where they will be there for their patients?"2

At many points, the conference felt like a revival meeting, as the collective tried to revive the central but assaulted notion ${ }^{3-6}$ that relationship is at the center of healing. ${ }^{7-15}$ At the center of what patients want, need, and increasingly do not think is available in a fragmented, depersonalized, often depersonalizing health care system. At the center of quality health care. At the center of family medicine.

Shiny new rattles enticed: newly won bobbles of prestige, enticements of lifestyle, being paid to "perform" on the sparse commodities of care that 
can be measured, ${ }^{16}$ "transformation" to a way of practicing that would finally garner respect, acceptance, and payment reform. ${ }^{17-22}$ But we desperately tried to hold onto the ideal - the way of being that gives meaning to family physicians and value to patients and populations - that primary health care is a relationship to be nurtured, not just a commodity to be delivered and optimized, measured and incentivized, bought and sold.

\section{What Might Being Countercultural Mean Today?}

Brought to the fore by Rosemary Stevens's ${ }^{23}$ historic witness to changes in US health care was Gayle Stephens's ${ }^{24}$ notion of family medicine as counterculture. When Dr. Stephens wrote of this, a tidal wave of countercultural revolution had already fomented family medicine into existence, as our forbearers willed a new mode of doctoring out of a timeless way of healing. ${ }^{25-39}$

But what about now? Is it ever more important to counter a culture that increasingly separates the haves and have nots? In which polarizing sound bites too often replace neighborly dialogue? In which greed, anger, and fear are fomented to gain or maintain power? In which the still, small, but powerful voices of generosity, kindness, and courage cry out unheard amid the churning hubbub?

Now that family medicine has achieved some measure of marginalized centrality, ${ }^{40}$ of acknowledgment without respect, ${ }^{41}$ of valuing without understanding, ${ }^{42}$ what might it mean to be countercultural in the current era? How much of being countercultural now involves letting go? How much involves holding on?

What if being countercultural now means:

- Getting over ourselves; vaporizing the dewdrops of self-regarding identity to merge into larger tides of change of which we can be a vital partbut only a part of a team, system, and community lurching toward an emerging, imperfectly seen collective good

- Recognizing, influencing, and riding the waves of larger interrelated change. Stephens, ${ }^{24}$ quoting Revel, ${ }^{43}$ recognized 5 interdependent revolutions that needed to happen simultaneously or not at all: political, social, cultural, technological/scientific, international/interracial.
- Working on multiple levels toward equitable treatment and environments that give everyone a fair shot

- Using every private and public opportunity to make space for real communication about real issues, rather than what currently passes for civil dialogue: sound bites designed to elicit an immediate visceral reaction that forces us into warring camps

- Teaching students the enduring values of family medicine, but freeing them to fulfill them in their own new way. Dr. Stephens wrote: "I would now rather be identified with student discontent than with the authority that imposes requirements on them."24

- Building learning communities ${ }^{44}$ and communities of solution ${ }^{45,46}$ that combine Big Data with deep, on-the-ground relationships to reinvent community-oriented primary care ${ }^{47-49}$

- Fighting against the widespread adoption of a line-worker approach to mass production that has largely been discredited in manufacturing but that is being applied full bore to public education and to delivering fragmented, depersonalized commodities of health care $\mathrm{e}^{50-56}$

- Standardizing what is common but not mistaking this for what is important: making room to take time with the particulars ${ }^{31}$ of person and place, family, and community

- Conducting research not as something that is done to rats, or to people treated like rats, or to subparts of people, and calling that "precision medicine," but as generating relevant new knowledge in partnership with practices, patients, and communities; adding stories to the statistics, narratives to the numbers ${ }^{57,58}$ - personalized medicine that requires knowing the person

- Integrated care ${ }^{59-61}$

- Embracing the measurement culture at arm's length ${ }^{16}$; working to assess what is important, empowering those on the front lines to move beyond metrics of central tendency toward personalized care, and making space and time for the important wonders that are beyond measurement

- Being the change we want to $\operatorname{see}^{62}$

I do not know if being countercultural is the proper political stance now. I do know that every day family physicians fly in the face of the fragmenting pressures of greed, anger, and fear, trying to do the right thing for individuals, families, and 
communities. Family medicine has been the buffer for a disjointed, depersonalizing, avaricious health care system for so long that the buffering capacity is nearly expended. We risk being the dead canaries in the mine of the unsustainable health care system.

But family medicine is more than the early warning system; it is the bedrock of any functional system. ${ }^{63}$ Rather than dying to let the miners escape, a dying family medicine risks collapsing the whole mine. In this situation it is important not only to be countercultural only in opposing the dysfunction, it is vital to champion viable alternatives-planting the kernels that, even if they do not thrive immediately, become part of the seed bank from which new life emerges when the current dysfunctional environment has burned itself out. And like new growth burgeoning from a scorched field, ${ }^{18}$ new alternatives are emerging, from personalized micropractices ${ }^{64-67}$ to large, single-specialty practices functioning as accountable care organizations $^{68}$ to direct primary care ${ }^{69}$ to highfunctioning community health centers and family practices that have found a way to coexist amid the dysfunction while showing a better way. ${ }^{70}$

\section{Stories}

At Keystone IV, many stories were told, and many more were held in participants' hearts as they attempted to discern features of family medicine that are too rich, complexly related, and personal to be reduced to inventories or averages. These are the attributes that defy easy metrics that can be centrally commanded and controlled. ${ }^{16}$ But these are also the elements that make primary care the cornerstone of an effective, equitable, sustainable health care system ${ }^{63,71}$ and that are the system's and society's best hope for achieving the quadruple aim of improved population health, patient experience, sustainable cost, and clinician/staff work life. ${ }^{72,73}$

On the first evening of the conference I told 1 of these stories. Here is one of the several others that I held in my heart.

The moment I walked into the examination room, I was wildly impressed by my 17 -yearold new patient. She was drop-dead gorgeous. Movie star striking. Blonde, shoulder-length hair framed a perfectly featured face with impeccable skin, sitting on a body that could sell magazines in either the men's or the women's section of the newsstand.
I moved to learn why she was here. She'd given birth to at the county hospital, and since her 6-week postpartum visit nearly a year ago at Planned Parenthood, she hadn't been out of the house where she lived with her son, her fiancé, and her father. She'd been feeling down. Crying spells. Not sleeping well. Not suicidal. Still able to attend to her son, but it took every ounce of her energy, and she felt dried up. She still was breastfeeding but starting to wean.

As she told her story, I was even more impressed by her articulate maturity. I learned that she was watching and waiting to see whether her fiancé really was husband material. He grew up rough; did not have a loving father like she did. But he was working night shifts and odd jobs to support them. He treated her OK despite his porn addiction. She never felt unsafe at home. Still, she was waiting to see whether he would be enough of a standup guy to stick with. It would be tough if she kicked him out. He did not have anywhere else to go. The medical assistant already had done the depression screening questionnaire, and the patient scored high. I commended her for breastfeeding so long and found that she wanted to continue at least the nightly feedings for a while. I looked up the antidepressant medication option with the least crossover into breast milk and electronically sent the prescription to the pharmacy next door. She agreed that counseling would be a good idea, and I told her about the counselors in our office and recommended the particular person I thought would be a good fit for her after the antidepressant medication kicked in and made it easier to get out of the house.

Her son was in the next room with his father. They were worried he had a tapeworm. No travel or well water; he's eating fine, growing and developing normally. I asked what, from our visit, I could share with her fiancé. Nothing? Everything? Something in between? She chose everything.

Exiting the room with her behind me, I exhaled slowly, letting the breath distribute to the Universe my feelings and thoughts about the visit, but keeping the essence with me. With the next slow breath, I considered my strategy for the visit to the room next door: 
check on the tapeworm concern, of course; assess the son's overall health and start a health promotion plan. The medical assistant had already cued up the immunization order for me to sign. But what about the fiancé? The last place a 17-year-old man wants to be is the doctor's office. But he's critically important to my 2 patients: his fiancé and son. OK. I will look for a little opportunity to connect with him. Maybe sports. Anything outside of medicine, an investment in a relationship that could become important. Maybe someday he'll even become my patient.

None of this nonmedical talk or thinking is billable of course. None of it gives any points on the quality or productivity measures. In fact, it often makes us look bad on the crude measures that misunderstand what is important about family medicine. ${ }^{74}$ But it is what family physicians do every day as they invest in developing relationships while being paid for delivering commodities.

I opened the door and stopped. The fiancé was drop-dead gorgeous. Movie star striking. A home-grown haircut framed a perfect face with just enough ruggedness to keep it from being pretty. A body honed not by workouts at a fancy gym, but from loading trucks night after night.

The young woman screamed and rushed around me to grab her son, who was trying to climb into the drawer he'd opened on the front of the examination table. Several cellophanewrapped plastic speculums were on the floor around him.

"You cannot just let him do whatever he wants! You have to watch him!"

"Bitch," he said under his breath. The "ch" struck a staccato note.

OK, change in plans, I thought to myself. I do not have the luxury of trying to connect through small talk. What I just witnessed has to be dealt with, now. But first, establish some credibility by dealing with the shared concern they both have about their son.

His cherub face, blonde hair, and chubby body could sell baby magazines. He obviously had good gross motor development to be standing and trying to climb into the drawer. He was not at all distressed by his mother's screech and swoop into her arms; he smiled disarmingly.
My examination revealed a healthy, well-developing boy. A look at the tapeworm in the glass jar, confirmed by a peek under the microscope, showed a pale, segmented, fibrous filament. "What are you feeding him?"

The list included carrots, precut from a bag, julienne-style-just the size of a tapeworm.

"Great idea to get him used to eating a lot of vegetables at an early age. It looks like his body is telling us it is not quite ready to digest a whole piece of carrot yet. His stomach juices can bleach the color out, but not break it down. So it comes out looking like a worm. Until he's a bit older, try grinding up his veggies, or you can buy them already ground up in little jars." While holding their son on my lap and handing him tongue depressors on which I'd drawn funny faces, I asked the couple to sit down together.

I spoke first to the fiancé. "Boys learn how to treat women by watching their fathers. Even though your son cannot say many words yet, he already is listening. He's learning what to say to his mother. Fathers have a lot of power to show their children how to do things righteven if that is different from how the father was treated growing up."

I told him that some of how his son's mother was acting was from depression, the kind that happens after you put your body through a lot by having a baby. But we had a plan to help her to be more like herself over the next few months. And he could help.

To both of them, I described the research showing that, in marriages that last, communication involves at least 5 times as many positive statements as negative ones. That is a big task when you are both stressed out, tired, working hard, and worried about the future. But before there are words, there are thoughts.

"I want you to both pay attention to every little thought you have about your partner. Look at whether it is a positive thought or a negative one. When it is a negative one, remember instead all the little things your partner has done for you. Remember the reasons you got together in the first place. Think about the new family you are trying to build together."

I leaned back and bounced their son on my knee as he smiled at all us. "Over time, you may find that the number of negative thoughts goes 
down, and the number of positive ones goes up. Thoughts lead to words and actions. Pay attention to your own thoughts, and words, and actions. Do not worry about the other person's reactions. When you do not like how they act, try to give them the benefit of the doubt. I have confidence that you can build the kind of relationship you want, and let your son witness that, and make it part of who he is."

Separately, they looked at me and nodded. They glanced at each other, held the gaze for a second, and then lowered their heads.

Over the next year, the woman's depression lifted, the son continued to develop beautifully, and the fiancé continued to work hard at night. He cared for the son during the day while the mother got a job driving a truck on local routes. The fiancé became the husband.

I saw them recently, together in a room, the father attending to the son drawing with crayons, the mother on the examination table as the patient. She'd gained 30 pounds and was in pain from a chronic back strain from hoisting heavy cartons off her truck. Her face looked at least a decade older. It made me think of my 40-year-old patients from disadvantaged backgrounds who look like they are in their 60s and have the medical profiles to match. This is how it starts, I thought.

I felt good about my first visit with this family. Someone auditing the medical records would give my team a decent quality score for treating postpartum depression and a fair score for a somewhat incomplete well-care visit of a 1-year-old. And I took too long to meet my "productivity" goals. The record is unseeing, and the quality metrics totally blind, to what was most valuable in that first visit- to a subtle intervention focused on fostering self-reflection about thoughts that lead to words and actions that cross generations. These are the things that family physicians are desperately trying to hold on to, even as we let go of our need to do everything ourselves and let the patient benefit from the full engagement of a diverse team.

We also are struggling to both let go of and hold on to our family and community focus. My practice gave up its family charts because all the electronic medical record vendors told us there was no business model for putting genograms in the electronic medical record. But we still try to keep the family focus. Research done in this practice and others in our network found that $18 \%$ of visits to family physicians involve care of a family member other than the identified patient. ${ }^{75}$ Half the time the other family member is not even in the room. Most of the time, this care is never billed for. ${ }^{76}$ We work to build new systems that will support us in faceto-face, electronic, and asynchronous care of families.

The Rockefeller Plaza-based branding company that did the research for the Future of Family Medicine Project that emerged from the prior Keystone III conference called the community focus of family medicine "its best kept secret." 77 As the scope and geographic span of our care diminishes and as pressures for so-called productivity increase, we struggle to carry forward this community contextualization of our care, even as we try to advance it with technology that brings aggregate and personal information on the social determinants of health-the larger forces that continue to disadvantage our patients from generation to generation, making them old before their time.

And so we continue to spend unpaid time trying to do what is important, even if it is not measured as quality or productivity. We continue to diagnose and treat and try to prevent diseases. We work to periodically raise our gaze from the disease to the person, from illness to health, and from individual to family to community to society. And more and more, we spend our thoughts, words, and actions on the community and society, trying to create space for all of us to see and act on our commonality.

\section{What to Let Go of, What to Hang on to}

Keystone IV, and the present moment, put before us the challenge to be clear and resolute about what to carry forward and what to let go of, what to fight for against all odds, what shackles to shed.

What if we give up:

- Our personal attachment to the hard-won bobbles of prestige

- Family medicine's apparently deep need to be found credible by powerful others

- The false dichotomy between systematically generating new knowledge and caring about, and 
pragmatically caring for, individuals, families, and communities

- Ways of acting that imply that if we just get the approach and messaging right, then the next generation, and the many partners we need to succeed, will get in line behind us

- The mainstream platforms that, like a waterskier's tow rope, have kept us above water, but in the fallen health care system, are now just dragging us under

- The notion that the needed changes are more about us and what we need than about partnership with others to change the environment that constrains and enables our working toward the collective good

What if we decide to retain but reinvent in a new information age:

- The commitment to a fair chance at health for everyone

- Our pledge to provide and promote health care that is integrated, personalized, prioritized, and sustainable

- The notions of community-oriented primary care, using data on the collective to inform and empower the individual, family, and community $^{78,79}$

- Our fundamental understanding that good health care is not just a commodity but a relationship based on the tenets of ${ }^{26,63,71,80-82}$ :

- being an accessible entry point with the health care system

- focusing on the whole person and what they need

- coordinating care that otherwise would be fragmented across settings and integrating care across acute and chronic illnesses, mental health, and prevention

- sustaining partnership by deeply knowing individuals, families, and community

- What if a new generation retains and reinvents the idea of being countercultural, not just as a reaction to the evil that we see around us, but as a wellspring of the potential we see in others and in ourselves? ${ }^{83}$

The natural impulse is to hold on to what has sustained you. It takes reflexivity to overcome the primitive grasping reflex. In moving toward the new ways that are needed in health care, it is vital to take time to consider what should be carried forward, and then to partner with others to reinvent health care on a robust and evolving foundation.

The author is grateful for the privilege of participating in the Keystone IV Conference, for Dr. Gayle Stephens's grounded countercultural vision and Dr. Rosemary Stevens rich historical perspective, and for support as a Scholar of the Institute for Integration Health and from a Clinical Research Professorship from the American Cancer Society.

\section{References}

1. Easwaran E. Essence of the Upanishads: a key to Indian spirituality. 3rd ed. Tomales, CA: Nilgiri Press; 2009.

2. G. Gayle Stephens Keystone conference series. May 27, 2015. Lextington, KY: American Board of Family Medicine. Available from: https://www. theabfm.org/about/news052715.aspx. Accessed June 5, 2016.

3. Kathol R, Saravay SM, Lobo A, Ormel J. Epidemiologic trends and costs of fragmentation. Med Clin North Am 2006;90:549-72.

4. Cebul RD, Rebitzer JB, Taylor LJ, Votruba M. Organizational fragmentation and care quality in the U.S. health care system. NBER working paper no. 14212. Cambridge, MA: National Bureau of Economic Research; 2008. Available from: http://www. nber.org/papers/w14212. Accessed June 5, 2016.

5. Stange KC. The problem of fragmentation and the need for integrative solutions. Ann Fam Med 2009;7: 100-3.

6. Hughes JR, Grayson R, Stiles FC. Fragmentation of care and the medical home. Pediatrics 1977;60:559.

7. Stange KC. The generalist approach. Ann Fam Med 2009;7:198-203.

8. Stange KC. Ways of knowing, learning, and developing. Ann Fam Med 2010;8:4-10.

9. Lanham HJ, McDaniel RR Jr, Crabtree BF, et al. How improving practice relationships among clinicians and nonclinicians can improve quality in primary care. Jt Comm J Qual Patient Saf 2009; 35:457-66.

10. Scott JG, Cohen D, Dicicco-Bloom B, Miller WL, Stange KC, Crabtree BF. Understanding healing relationships in primary care. Ann Fam Med 2008; 6:315-22.

11. Beach MC, Inui T. Relationship-centered care. A constructive reframing. J Gen Intern Med 21 Suppl 1:S3-8, 2006.

12. Stewart M. Reflections on the doctor-patient relationship: from evidence and experience. Br J Gen Pract 2005;55:793-801.

13. Charon R. The seasons of the patient-physician relationship. Clin Ger Med 2000;16:37-50.

14. Loxterkamp D. Card of thanks: a personal note on the physician-patient relationship. J Am Board Fam Pract 1996;9:380-1. 
15. Epstein RM, Fiscella K, Lesser CS, Stange KC. Why the nation needs a policy push on patientcentered health care. Health Aff (Millwood) 2010; 29:1489-95.

16. Stange KC, Etz RS, Gullett H, et al. Metrics for assessing improvements in primary health care. Annu Rev Public Health 2014;35:423-42.

17. Cronholm PF, Shea JA, Werner RM, et al. The patient centered medical home: mental models and practice culture driving the transformation process. J Gen Intern Med 2013;28:1195-201.

18. Stange KC, Ferrer RL, Miller WL. Making sense of health care transformation as adaptive-renewal cycles. Ann Fam Med 2009;7:484-7.

19. Nutting PA, Miller WL, Crabtree BF, Jaén CR, Stewart EE, Stange KC. Initial lessons from the first national demonstration project on practice transformation to a patient-centered medical home. Ann Fam Med 2009;7:254-60.

20. Geyman J. The corporate transformation of health care: can the public interest still be served? New York: Springer Publishing; 2004.

21. Gunderson LH, Holling CS, eds. Panarchy: understanding transformations in human and natural systems. Washington, DC: Island Press; 2002.

22. Borkan JM, Reis S, Medalie JH. Narratives in family medicine: tales of transformation, points of breakthrough for family physicians. Fam Sys Health 2001; 19:121-34.

23. Stevens RA. Recharging family medicine: a perspective from the Keystone IV conference. J Am Board Fam Med 2016;29:S15-S18.

24. Stephens GG. Family medicine as counterculture. Fam Med 1989;21:103-9.

25. Stephens GG. The intellectual basis of family practice. Tucson, AZ: Winter Publishing; 1982.

26. McWhinney IR, Freeman T. Textbook of family medicine. 3rd ed. New York: Oxford University Press; 2009.

27. McWhinney IR. Time, change, and family practice. Can Fam Physician 2001;47:1365-7, 1374-6.

28. McWhinney IR. The importance of being different. Part 1: the marginal status of family medicine. Can Fam Physician 1997;43:193-5, 203-5.

29. McWhinney IR. William Pickles Lecture 1996. The importance of being different. Br J Gen Pract 1996; 46:433-6.

30. McWhinney IR. Why we need a new clinical method. Scand J Prim Health Care 1993;11:3-7.

31. McWhinney IR. An acquaintance with particulars. Fam Med 1989;21:296-8.

32. McWhinney IR. Fine words, but will he deliver? CMAJ 1987;136:473-4.

33. McWhinney IR. Family medicine as a science. J Fam Pract 1978;7:53-8.

34. McWhinney IR. The naturalist tradition in general practice. J Fam Pract 1977;5:375-8.
35. McWhinney IR. The primary physician in a comprehensive health service. Further reflections after a visit to the United States. Lancet 1967;1:91-6.

36. McWhinney IR. General practice as an academic discipline: reflections after a visit to the United States. Lancet 1966;1:419-23.

37. Medalie JH. Family medicine: principles and applications. Baltimore: Williams \& Wilkins; 1978.

38. Geyman JP, Hart LG. Primary care at a crossroads: progress, problems, and future projections. J Am Board Fam Pract 1994;7:60-70.

39. Geyman JP, Berg AO. The Journal of Family Practice 1974-1983: analysis of an evolving literature base. J Fam Pract 1984;18:47-51.

40. Newton WP, DuBard CA. Shaping the future of academic health centers: the potential contributions of departments of family medicine. Ann Fam Med 2006;4(Suppl 1):S2-11.

41. Task Force 1 Writing Group; Green AG, Graham R, Bagley B, et al. Task Force 1. Report of the Task Force on Patient Expectations, Core Values, Reintegration, and the New Model of Family Medicine. Ann Fam Med 2004;2(Suppl 1):S33-50.

42. Starfield B. Family medicine should shape reform, not vice versa. Fam Pract Manag 2009;16:6-7.

43. Revel JF. Without Marx or Jesus. Saturday Review of Literature, July 24, 1971.

44. Aungst H, Ruhe M, Stange KC, et al. PHAB Staff and Writing Committee; PHAB Cleveland Advisory Committee. Boundary spanning and health: invitation to a learning community. London J Prim Care (Abingdon) 2012;4:109-15.

45. Griswold KS, Lesko SE, Westfall JM. Communities of solution: partnerships for population health. J Am Board Fam Med 2013;26:232-8.

46. Folsom Group. Communities of solution: the Folsom Report revisited. Ann Fam Med 2012;10:250-60.

47. Nutting PA. Community-oriented primary care: an integrated model for practice, research, and education. Am J Prev Med 1986;2:140-7.

48. Mullan F, Epstein L. Community-oriented primary care: new relevance in a changing world. Am J Public Health 2002;92:1748-55.

49. Rhyne R, Bogue R, Kukulka G, Fulmer H, eds. Community-oriented primary care: health care for the 21st century. Washington, DC: American Public Health Association; 1998.

50. Kaplan HC, Froehle CM, Cassedy A, Provost LP, Margolis PA. An exploratory analysis of the Model for Understanding Success in Quality. Health Care Manage Rev 2012;38:325-38.

51. Øvretveit J. Understanding the conditions for improvement: research to discover which context influences affect improvement success. BMJ Qual Saf 2011;20(Suppl 1):i18-23.

52. Crabtree BF, Nutting PA, Miller WL, et al. Primary care practice transformation is hard work: insights 
from a 15-year developmental program of research. Med Care 2011;49(Suppl):S28-35.

53. Alexander JA, Hearld LR. The science of quality improvement implementation: developing capacity to make a difference. Med Care 2011;49(Suppl):S6-20.

54. Ruhe MC, Carter C, Litaker D, Stange KC. A systematic approach to practice assessment and quality improvement intervention tailoring. Qual Manag Health Care 2009;18:268-77.

55. Miller WL, Crabtree BF, Stange KC, Nutting PA, Jaén CR. Primary care practice development: a relationship-centered approach. Ann Fam Med 2010; 8(Suppl 1):S68-79.

56. Willis J. Friends in low places. Abingdon, Oxon, UK: Radcliffe Medical Press; 2001.

57. Balasubramanian B, Cohen D, Davis M, et al. Learning evaluation: blending quality improvement and implementation research methods to study healthcare innovations. Implement Sci. 2015;10:31.

58. Stange KC, Miller WL, McWhinney I. Developing the knowledge base of family practice. Fam Med 2001;33:286-97.

59. Cohen DJ, Balasubramanian BA, Davis M, et al. Understanding care integration from the ground up: five organizing constructs that shape integrated practices. J Am Board Fam Med 2015;28(Suppl 1):S7-20.

60. World Health Organization. Integrated health services - what and why. Technical brief no. 1, 2008. Available from: http://www.who.int/healthsystems/ service_delivery_techbrief1.pdf. Accessed June 5, 2016.

61. Thomas P. Integrating primary health care: leading, managing, facilitating. Oxford, UK: Radcliffe Publishing; 2006.

62. Easwaran E. Gandhi the man. 3rd ed. Petaluma, CA: Nilgiri Press; 1997.

63. Starfield B, Shi LY, Macinko J. Contribution of primary care to health systems and health. Milbank Q 2005;83:457-502.

64. Glancey KK, Kennedy JG. Achieving PCMH status may not be meaningful for small practices. Ann Fam Med 2016;14:4-5.

65. Moore LG, Wasson JH, Johnson DJ, Zettek J. The emergence of ideal micro practices for patient-centered, collaborative care. J Ambul Care Manage 2006;29:215-21.

66. Liaw WR, Jetty A, Petterson SM, Peterson LE, Bazemore AW. Solo and small practices: a vital, diverse part of primary care. Ann Fam Med 2016;14: $8-15$.

67. Mostashari F. The paradox of size: how small, independent practices can thrive in value-based care. Ann Fam Med 2016;14:5-7.
68. Casalino LP, Chen MA, Staub CT, et al. Large independent primary care medical groups. Ann Fam Med 2016;14:16-25.

69. Wu WN, Bliss G, Bliss EB, Green LA. Practice profile. A direct primary care medical home: the Qliance experience. Health Aff (Millwood) 2010;29: 959-62.

70. Sinsky CA, Willard-Grace R, Schutzbank AM, Sinsky TA, Margolius D, Bodenheimer T. In search of joy in practice: a report of 23 high-functioning primary care practices. Ann Fam Med 2013;11:272-8.

71. Donaldson MS, Lohr KN, Vanselow NA, eds. Primary care: America's health in a new era. Washington, D.C.: National Academy Press; 1996.

72. Bodenheimer T, Sinsky C. From triple to quadruple aim: care of the patient requires care of the provider. Ann Fam Med 2014;12:573-6.

73. Berwick DM, Nolan TW, Whittington J. The triple aim: care, health, and cost. Health Aff (Millwood) 2008;27:759-69.

74. Stange KC, Ferrer RL. The paradox of primary care. Ann Fam Med 2009;7:293-9.

75. Flocke SA, Goodwin MA, Stange KC. The effect of a secondary patient on the family practice visit. $\mathrm{J}$ Fam Pract 1998;46:429-34.

76. Orzano AJ, Gregory PM, Nutting PA, Werner JJ, Flocke SA, Stange KC. Care of the secondary patient in family practice. A report from the Ambulatory Sentinel Practice Network. J Fam Pract 2001;50: 113-6.

77. Martin JC, Avant RF, Bowman MA, et al; Future of Family Medicine Project Leadership Committee. The Future of Family Medicine: a collaborative project of the family medicine community. Ann Fam Med 2004;2(Suppl 1):S3-32.

78. Sweeney SA, Bazemore A, Phillips RL Jr, Etz RS, Stange KC. A reemerging political space for linking person and community through primary health care. Am J Public Health 2012;102(Suppl 3):S336-41.

79. Sweeney SA, Bazemore A, Phillips RL Jr, Etz RS, Stange KC. A re-emerging political space for linking person and community through primary health care. Am J Prev Med 2012;42(6 Suppl 2):S184-90.

80. Starfield B. Primary care: balancing health needs, services, and technology. Rev. ed. New York, NY: Oxford University Press; 1998.

81. Stange KC, Nutting PA, Miller WL, et al. Defining and measuring the patient-centered medical home. J Gen Intern Med 2010;25:601-12.

82. Stange KC, Jaén CR, Flocke SA, Miller WL, Crabtree BF, Zyzanski SJ. The value of a family physician. J Fam Pract 1998;46:363-8.

83. Scherger JE. Family medicine needs a generation of dreamers. Fam Med 2006;38:363-4. 